- The Westenn New Yonx/Ontanio ChapTER of ACRL has selected new officers. The results of the elections are:

Vice-President-Betty Miller, supervisor of the Calspan Corporation Technical Library, Buffalo, New York

Secretary-Stephen Kees, senior librarian, Niagara College of Applied Arts and Technology, Welland, Ontario

Treasurer-Jo Ann Kaufman, assistant librarian in education, State University of New York, College at Fredonia

Membership Chairperson-Maryruth Glogowski, assistant librarian, E. H. Butler Library, State University of New York, College at Buffalo

Nominations Chairperson-Paul Zadner, associate librarian, E. H. Butler Library, State University of New York, College at Buffalo

Program Chairperson-David Legel, psy- chology bibliographer, Rush Rhees Library, University of Rochester, New York

Public Relations Chairperson-John Kilbury, information and orientation librarian, University of Guelph, Ontario

Councilor-Barbara Mann, assistant librarian, Science and Engineering Library, State University of New York at Buffalo

Councilor-Sheila Laidlaw, librarian, Sigmund Samuel Library, University of Toronto, Ontario

- The Onegon Chapter of ACRL held a training session and workshop on January 25 at which Ted Ryerson of National Technical Information Service (NTIS) talked about their services and publications. He also provided information on developing search strategies for computer access. It was jointly sponsored by the University of Oregon. Ninety-five people attended.

\title{
Proposed Amendment to the ACRL Constitution and Bylaws
}

Upon the recommendation of the ACRL Publications Committee and the ACRL Board of Directors, the following text was proposed by the Committee on the ACRL Constitution and Bylaws as an addition to the ACRL Constitution and Bylaws (published in the April 1973 issue of College \& Research Libraries News). If approved, the proposed text would become Article VII of the ACRL Bylaws, and the current Bylaws Articles VII, VIII, IX, and $X$ would be renumbered.

The ACRL Bylaws may be amended by a majority vote of the members of the Association attending a general meeting at an annual conference or casting ballots in a vote by mail, provided that notice of the proposed changes has been published not less than one month before the final consideration. The proposed Bylaw will be considered for approval at the ACRL Membership Meeting at the Detroit Conference on Saturday, June 18, 1977, at 2:00 p.m.

\section{BYLAWS}

Article VII. Publications Programs

Sec. 1. Authorization. The publications programs of the Association shall be authorized by action of the Association or the Board of Directors, except as otherwise provided in the Constitution and Bylaws, and subject to the policies and procedures of the American Library Association. The Board of Directors shall approve the policy and manner of distribution of publications, exercise financial control, and establish criteria and recruitment policies for selection and appointment of editors and editorial boards, as appropriate.

\section{Recent LA's (Library Acronyms) Encountered}

BLAISE (British Library Automated Information Service)

NASIC (Northeast Academic Science Information Center)

PRECIS (Preserved Context Indexing System)

SCATT (Scientific Communication and Technology Transfer)

SPIN (Searchable Physics Information Notices )

TINA (Technology Innovation Alert) 